\title{
USING GIS TO ASSESS URBAN TREE CANOPY BENEFITS AND SURROUNDING GREENSPACE DISTRIBUTIONS
}

\author{
by Mark C. Dwyer ${ }^{1}$ and Robert W. Miller ${ }^{2}$
}

\begin{abstract}
CITYgreen ${ }^{\circledR}$, a geographic information system (GIS)-based program, was used to evaluate selected benefits provided by the tree canopy in the city of Stevens Point, Wisconsin. We assessed the distribution of open space in and around the greater Stevens Point area, energy savings from lowered air-conditioning costs, and the reductions in stormwater runoff as a partial function of existing tree canopy. Estimated annual energy savings for residential areas in Stevens Point and surrounding communities was $\$ 126,859$. A storm delivering $6.6 \mathrm{~cm}$ (2.6 in.) of rain in 24 hours will deposit just under 2 billion L ( 530 million gal) of water on Stevens Point, of which 400 million L (106 million gal) will run off into the Wisconsin River. Approximately $6 \%$ of Stevens Point is covered by impervious surfacing, which accounts for $24 \%$ of the city's total stormwater runoff volume. Orthophotographs were digitized on screen, and land surrounding Stevens Point was classified based on vegetation cover, land use, and current zoning. Land use in the greater Stevens Point area $(22,250$ ha $[55,000 \mathrm{ac}])$ is $20.7 \%$ developed, $24.1 \%$ agriculture, $46.8 \%$ undeveloped, and $8.4 \%$ surface water. Planners, managers, elected officials, and other interested parties in land-use planning for the region are using the results of this study for open-space planning.
\end{abstract}

Key Words. Geographic information systems; GIS; tree canopy; greenspace; stormwater runoff; planning; energy savings, urban forest.

Identifying and describing the benefits of the urban forest to a community is the first step in gaining support for an urban forestry program of tree planting, maintenance, and replacement. Similarly, community planners require information regarding current land-use and open-space distributions in order to direct future patterns of growth and greenspace development. Urban forest structure, defined by the size, species composition, and location of urban trees, is typically expressed as a percentage of tree canopy cover over a city, and is an indicator of the contributions of the urban forest (Nowak 1991). Urban tree canopies reduce summer cooling (air-conditioning) costs by shading structures and air conditioners. The magnitude of cooling energy savings due to direct tree shade depends on tree placement, crown shape, crown density, growth rate, and longevity (McPherson and Rowntree 1993), as well as the age of building construction, occupant behavior, window location, and seasonal solar angles (Simpson and McPherson 1996). The individual homeowner can obtain substantial savings from optimal tree shade, but greater benefits will accrue for the community as a whole due to the combined effect of the overall urban canopy on the local climate. Reduced demand for air-conditioning energy will lower the amount of fossil fuel and/or water consumed by power plants, resulting in both conserved water and reduced emissions of carbon dioxide and other pollutants from smokestacks (McPherson 1991; Nowak 1995).

Urbanization increases the land area that is covered with impermeable surfaces such as streets, sidewalks, driveways, and building rooftops. Rain falling on these surfaces flows quickly into sewers, increasing the incidence and severity of flooding (McPherson 1990). Tree canopies intercept rainfall, thereby reducing peak discharge into stormwater sewers. This interception allows for groundwater recharge, reduces the cost of stormwater disposal, and averts flooding and sedimentation of waterways. Slope, soil type, amount of rain, and other factors also affect stormwater runoff rates. The amount of tree canopy in urban environments, however, is a "controllable" element that significantly and measurably affects stormwater runoff rates and volumes.

To ensure future contributions of the urban forest, urban foresters must frequently look beyond the community at larger systems of forest and other open space that has potential to be preserved or conserved as land is converted for residential, commercial, and industrial use. A comprehensive planning approach, 
frequently encompassing multiple jurisdictions, could plan development patterns so as to maintain natural areas and greenspace while allowing for growth.

Examining patterns of land use and land ownership, along with vegetation patterns and other natural features, allows urban foresters and planners to more appropriately plan for changes in land use that will consider natural resource distributions. These urban forests may include remnant forests, riparian corridors, and other open space. As urban forests are considered in land-use plans, the ability of the urban forest to contribute to environmental quality also increases, thereby yielding a return on the city's investment (Macie 1994). Aside from individual tree benefits, collective systems of urban forests offer additional benefits to the community. They provide recreation opportunities, trap eroded sediments and soilborne pesticides and herbicides, moderate temperature extremes and air pollution, and provide wildlife habitat and species dispersal routes (Thorne 1993).

Recent developments in technology have allowed for an accurate and comprehensive assessment of the structure and benefits provided by urban forests. Aerial photographs combined with remotely sensed spatial data provide an overview of natural resources and land use. When used in conjunction with GIS technology, information on urban forests can be analyzed and updated. GIS reduces the time needed for map production, revisions, and information storage while allowing for the combination of data "layers" and the timely analysis of spatial variables.

\section{STUDY AREA}

We characterized our study area as the greater Stevens Point area. With a population of 40,000 (1990 census), this area includes the city of Stevens Point, 3 villages, and 5 townships covering 22,250 ha $(55,000 \mathrm{ac})$. This area was selected because it encompasses the majority of urban development in the county, has varied land use and natural resources, and is experiencing rapid urban development.

\section{METHODS: DEVELOPED LANDS Energy Savings}

Energy savings from lowered air-conditioning costs due to tree shade for Stevens Point and 3 adjacent villages were computed using CITYgreen ${ }^{\circledR}$, specialized GIS software developed by American Forests (1516 P Street NW, P.O. Box 2000, Washington, DC
20013). Only residential areas were examined. This program takes spatial data layers, performs overlay analysis, and computes energy savings.

Two primary layers of information are used for energy savings analysis; land use and land cover. CITYgreen combines these features into "EcoStructures." Additional field data is then applied to these EcoStructures to compute energy savings.

Land-use information for the city of Stevens Point and the 3 adjacent villages was gathered from existing municipal maps and put into a GIS digital format. Each land-use area was assigned a value corresponding to a land-use category based on the Anderson Land Use Classification System (Table 1). This classification system is used in CITYgreen.

The land-cover layer was developed using criteria required by CITYgreen. Land cover consists of the following 3 elements represented as percentages of cover: 1) tree canopy, 2) grass/herbaceous, and 3) impervious surface. The combined percentage of these 3 elements equals 100\% for each land-cover classification. CITYgreen consolidates the percentages into 5 categories (Table 2). Land-cover informa-

Table 1. Land-use categories* in the Stevens Point area.

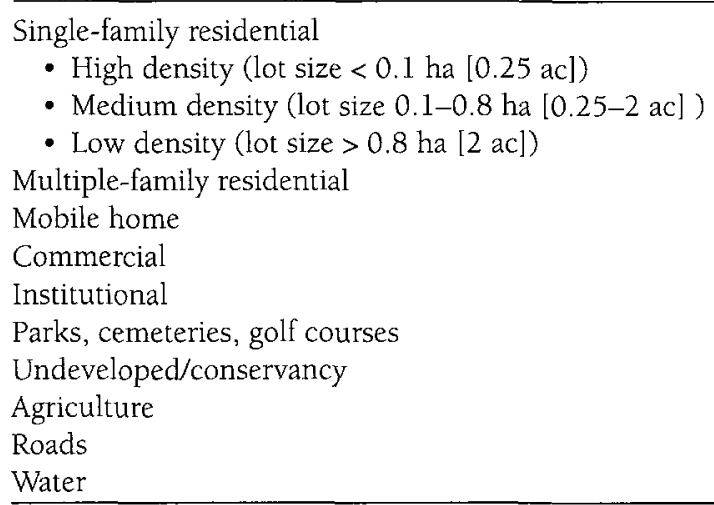
Survey Professional Paper \#964, 1976.

Table 2. Land-cover delineations applied to tree canopy, turf, and impervious surfaces.

\begin{tabular}{ll}
\hline Coverage category & Percentage range \\
\hline Very light & $0-5 \%$ \\
Light & $6-20 \%$ \\
Medium & $21-40 \%$ \\
Heavy & $41-60 \%$ \\
Covered & $>60 \%$ \\
\hline
\end{tabular}


tion for the urban study area was determined using black-and-white, stereo-infrared aerial photographs (taken in 1992) at a scale of $1: 15,840$, provided by the Wisconsin Department of Natural Resources. Land-cover classifications were determined on a block-by-block basis.

After creating EcoStructures for Stevens Point, we applied field data from the city of Milwaukee, Wisconsin. A comprehensive inventory of relative tree data was not available for Stevens Point or the adjacent villages. Patterns of land use and tree canopy cover, as well as summer air-conditioning usage variables, are similar in Stevens Point and Milwaukee, allowing the use of field data from Milwaukee. The field data consist of information on crown size, location, species, ownership, trunk diameter, total height, health, and conflicts. Each tree was assigned an energy rating that indicated its shading ability and effectiveness. Savings multipliers were then applied for all trees by EcoStructure, producing an estimated dollar amount in energy savings.

\section{Stormwater Benefits}

CITYgreen was used for stormwater analysis of Stevens Point and was based on elements of precipitation information, hydrologic soil group, and landcover class. Only the city of Stevens Point was examined. Precipitation data were for a 2-year, 24 hour storm event of $6.6 \mathrm{~cm}$ (2.6 in.) of rainfall. Soils were grouped into 4 categories according to their drainage characteristics. The land-cover layer provided information on the amount of impervious surface in each EcoStructure. Stormwater runoff rates were classified as a percentage of rainfall that initially runs off site, based on the above elements; these percentages were then grouped into 5 "runoff amount" categories (Table 3).

\section{METHODS: UNDEVELOPED LANDS Open-Space Distribution}

The greater Stevens Point area was classified into 19 land-use/land-cover categories through the onscreen digitizing of 1992 orthophotographs in a GIS using the ArcEDIT ${ }^{\circledR}$ module of ARC/INFO ${ }^{\circledR}$ developed by ESRI (380 New York St., Redlands, CA 92373, [800] 447-5953). CITYgreen was not used for this analysis. These categories were further consolidated into the classifications of undeveloped, developed, agriculture,
Table 3. Stevens Point stormwater runoff by categories and percentages of the city. ${ }^{*}$

\begin{tabular}{lllc}
\hline $\begin{array}{l}\text { Tree cover/ } \\
\text { impervious surface }\end{array}$ & $\begin{array}{l}\text { Runoff } \\
\text { amount (\%) }\end{array}$ & $\begin{array}{l}\% \text { of } \\
\text { total area }\end{array}$ & $\begin{array}{c}\% \text { of total } \\
\text { runoff }\end{array}$ \\
\hline $\begin{array}{l}\text { Heavy canopy/ } \\
\text { light impervious }\end{array}$ & Very light (0-5\%) & 30 & 1.6 \\
$\begin{array}{c}\text { Medium/heavy canopy/ } \\
\text { light impervious }\end{array}$ & Light (6-20\%) & 32 & 15.0 \\
$\begin{array}{c}\text { Medium canopy/ } \\
\text { medium impervious }\end{array}$ & Medium (21-40\%) & 21 & 31.1 \\
$\begin{array}{c}\text { Low canopy/ } \\
\text { medium-heavy impervious } \\
\text { Minimal canopy/ } \\
\text { covered impervious }\end{array}$ & $\begin{array}{l}\text { Heavy-intense } \\
(61-100 \%)\end{array}$ & 6 & 24.5 \\
\hline
\end{tabular}

* Based on a precipitation event (2-year, 24-hour) that will deposit $1,968,356,000 \mathrm{~L}(519,645,984 \mathrm{gal})$ of rainfall within the city limits of Stevens Point. Of this amount, 413,357,164 L $(109,126,291)$ will flow into the Wisconsin. River as runoff. Refer to Table 2 for breakdowns of canopy and impervious delineations.

and water cover (Figure 1). Orthophotographs represent true earth coordinates that have been corrected for discrepancies caused by camera error or displacements due to topographical differences. A rural zoning layer describing 12 zoning categories was compiled from existing digital sources and maps.

Combining the land-use and zoning layers in GIS allowed for a single coverage containing the combined information from both sources. Using such criteria as land cover, zoning, size, and location, lands were identified for possible protection based on their proximity to an existing greenway that circles through the study area.

\section{RESULTS}

\section{Energy Savings}

The estimate for annual energy savings as a result of tree shade and lowered air-conditioning costs for all of the urban residential areas in the study area is $\$ 126,859$ as determined by CITYgreen.

\section{Stormwater Benefits}

A 2-year, 24-hour storm event of $6.6 \mathrm{~cm}$ (2.6 in.) will deposit 2 billion L (530 million gal) of stormwater on Stevens Point. Of this amount, 400 million L (106 million gal) will run off into the Wisconsin River. Six percent of Stevens Point is covered by buildings and concrete with few trees, and accounts for $24.5 \%$ of the total stormwater runoff for the city. Areas with heavy tree canopy have much lower runoff rates and volumes (Table 3). 


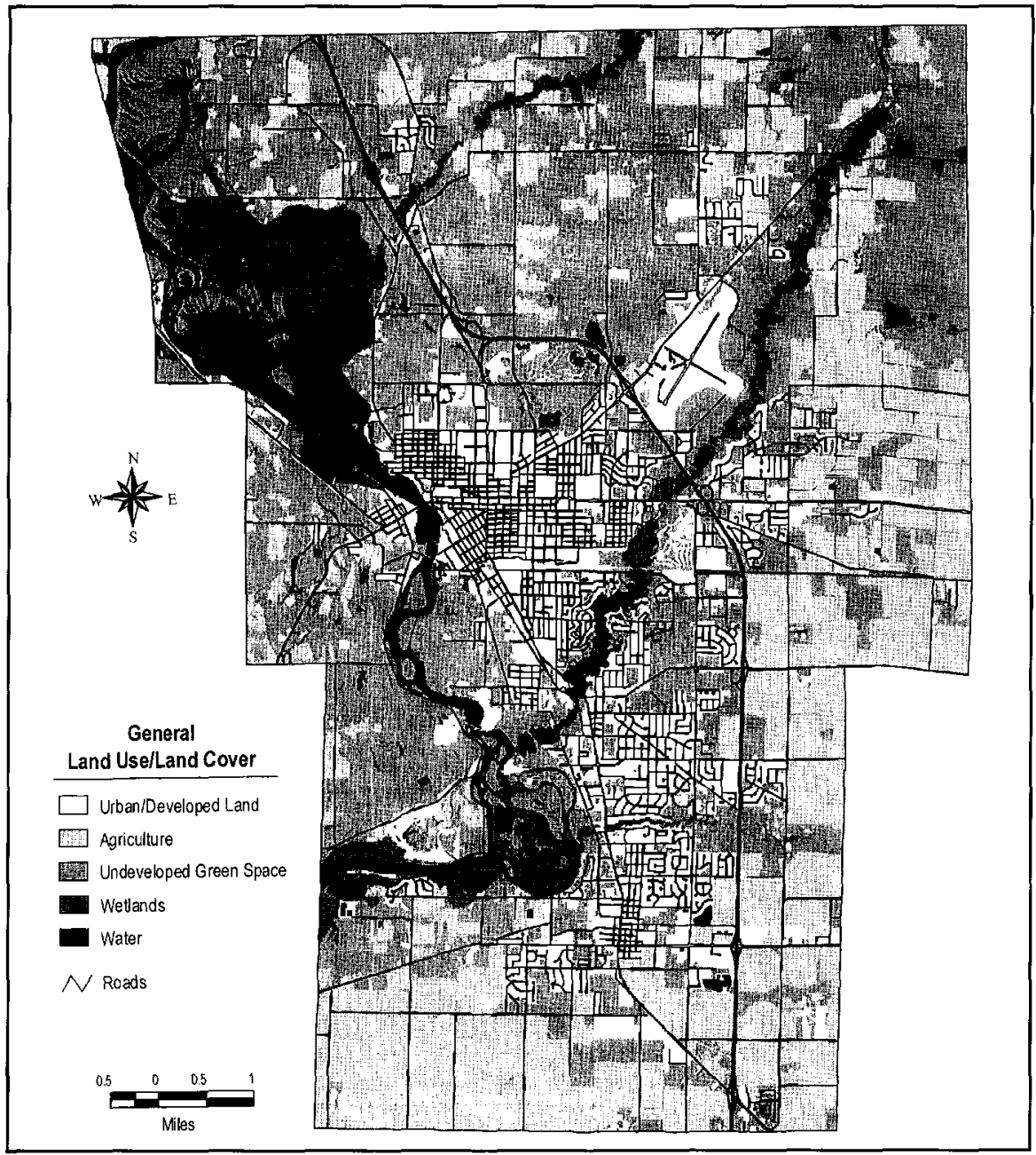

Figure 1. Greater Stevens Point area land use/land cover. regarding the future of remaining open spaces. Many priority lands located in rural areas are prime for development as increasing land value and re-zoning initiatives may claim these natural areas.

\section{DISCUSSION}

The objective of this study was to develop a model that examines distributions of trees and natural systems in and around Stevens Point and quantifies some of the benefits they provide. This information will help planners, city managers, and other decision-makers properly plan for the urban forest. The relationships between urban forest structure and function, when quantified, will allow managers to create and maintain functional and beneficial urban forests (Nowak 1991). Energy savings and stormwater runoff reduction are 2 of the benefits of urban forests that can be quantified and appropriately used in urban forest planning and management. With urban development expanding into rural areas, there is a need to examine existing forest resources and recommend patterns of protection to guide development and preserve tree canopy.

Tools such as GIS allow for large-scale assessments for open-space planning that can include parks, forests, and possible greenway linkages. These spatial analyses and inventories provide current, comprehensive information vital to open-space decision-making and identify opportunities for a coordinated effort to guide urban development in a manner that will take advantage of all the social and ecological functions available from the urban forest. tively used, possibly because of the quantity of remaining forests on these lands. There is concern 


\section{LITERATURE CITED}

Macie, E. 1994. The urban forest component of public infrastructure, pp 30-33. In Proceedings of the Sixth National Urban Forest Conference. Minneapolis, MN. Sept. 14-18, 1993. American Forests, Washington, DC.

McPherson, E.G. 1990. Economic modeling for large-scale urban tree plantings. In Proceedings of the ACEEE 1990 Summer Study on Energy Efficiency in Buildings. American Council for an Energy Efficient Economy, Washington, DC.

McPherson, E.G. 1991. Environmental benefits and costs of the urban forest, pp 52-54. In Proceedings of the Fifth National Urban Forest Conference. Los Angeles, CA. Nov. 12-17, 1991. American Forestry Association, Washington, DC.

McPherson, E.G., and R.A. Rowntree. 1993. Energy conservation potential of urban tree planting. $J$. Arboric. 19:321-331.

Nowak, D.J. 1991. Urban forest structure and the functions of hydrocarbon emissions and carbon storage, pp 48-51. In Proceedings of the Fifth National Urban Forest Conference. Los Angeles, CA. Nov. 12-17, 1991. American Forestry Association, Washington, DC.

Nowak, D.J. 1995. Trees pollute? A "TREE" explains it all, pp 28-30. In Proceedings of the Seventh National Urban. Forest Conference. New York, NY. Sept. 12-16, 1995. American Forests, Washington, DC.
Simpson, J.R., and E.G. McPherson. 1996. Potential of tree shade for reducing residential energy use in California. J. Arboric. 22:10-18.

Thorne, J.F. 1993. Landscape ecology: A foundation for greenway design, pp 23-42. In Smith, D.S., and P.C. Hellmund (Eds.). Ecology of Greenways. 1993. University of Minnesota Press, Minneapolis, MN.

Acknowledgements. This project was funded by a cooperative community forestry assistance grant in conjunction with the City of Stevens Point, the Wisconsin Department of Natural Resources, the University of Wisconsin-Stevens Point, Portage County Planning and Zoning Department, and American Forests.

${ }^{1 *}$ Landscape Manager

Rotary Gardens

Janesville, WT 53545

${ }^{2}$ Professor

College of Natural Resources

University of Wisconsin-Stevens Point

Stevens Point, WI 54481

${ }^{*}$ Corresponding author 
Résumé. Un système d'information géographique (GIS) a été utilisé pour évaluer des bénéfices précis du couvert arboré dans la ville de Stevens Point (Wisconsin) ainsi que la distribution des espaces dits ouverts dans la grande région de Stevens Point. Le logiciel CITYgreen a été utilisé pour mesurer les économies d'énergie engendrées par des besoins plus faibles en air climatisé ainsi que pour quantifier la réduction du ruissellement d'eau de surface lors diorages, et ce en fonction du couvert forestier urbain existant. Environ 6\% de Stevens Point est dominé par des surfaces imperméables comportant très peu d'arbres et qui comptent pour $24 \%$ du volume total de la ville en eau de ruissellement de surface. Des orthophotos digitales ont été mises à l'écran et le territoire entourant Stevens Point a été classifié en fonction du couvert végétal, de son utilisation et du zonage courant. La grande région de Stevens Point ( $22250 \mathrm{ha}$ ) est développée à $20,7 \%, 24,1 \%$ est agricole, $46,8 \%$ n'est pas développé et $8,4 \%$ est composé de plans d'eau. Les résultats de cette étude ont été utilisés par les planificateurs, les gestionnaires, les politiciens et les autres intéressés à des fins courantes de planification de l'utilisation du territoire.

Zusammenfassung. GIS wurde angewandt, um die Vorteile von ausgewählten Baumkronen in der Stadt Stevens Point, Wisconsin und die Verteilung größerer Freiflächen in dem Großraum von Stevens Point zu bewerten. CITYgreen, ein auf GIS basierendes Programm, wurde hier angewandt, um die Energieeinsparungen durch verminderte Kosten für Klimaanlagen und die Reduktion des Regenwasserablaufs als eine Funktion der existierenden Baumkronen zu mesen. Schätzungsweise $6 \%$ der Fläche von Stevens Point ist versiegelt mit einigen wenigen Bäumen, wobei hier 24\% des Gesamtvolumens des Oberflächenablaufwassers werden. Auf dem Bildschirm wurde ein digitales Bildwerk erstellt und das Umland von Stevens Point wurde basierend auf der Vegetationsbedeckung, Landnutzungsgrad und gegenwärtige Zonenunterteilung klassifiziert. Das Umland von Stevens Point ( 22.250 ha) ist zu $20,7 \%$ entwickelt, $24,1 \%$ besteht aus Landwirtschaft, 46,8\% ist nicht entwickelt und $8,4 \%$ entfallen auf Wasserflächen. Die Ergebnisse dieser Studie werden von Planern, Managern, höheren Angestellten und anderen interessierten Parteien, die sich mit Landnutzung befassen, genutzt.

Resumen. Se utilizó GIS para evaluar los beneficios del dosel de árboles urbanos seleccionados, y la distribución del espacio abierto en las áreas más grandes, en la ciudad de Stevens Point, Wisconsin. Fue usado CITYgreen, un programa basado en GIS, para medir los ahorros de energía de acondicionadores de aire, y la reducción del escurrimiento en las tormentas como una función del dosel forestal urbano existente. Aproximadamente el $6 \%$ de Stevens Point es dominado por superficies imper-meables con muy pocos árboles y responde por el $24 \%$ del volumen total de escurrimiento en la ciudad. Se usó ortofotografía digital sobre pantalla, y el terreno circun-dante a Stevens Point fue clasificado con base en cobertura vegetal, uso del suelo y zonificación actual. El área más grande de Stevens Point $(22,250$ ha) está desarrollada en un $20.7 \% ; 24.1 \%$ es agricultura, $46.8 \%$ es no desar-rollada y $8.4 \%$ es agua superficial. Los resultados del este estudio están siendo usados por planeadores, admini-stradores, oficialidades electas, y otras partes interesadas en llevar adelante la planeación del uso del suelo. 